University of Nebraska - Lincoln

DigitalCommons@University of Nebraska - Lincoln

\title{
Mitigation of Shallow Groundwater Nitrate in a Poorly Drained Riparian Area and Adjacent Cropland
}

Jennifer H. Davis

USDA-ARS

Stephen M. Griffith

USDA-ARS

William R. Horwath

University of California, Davis, wrhorwath@ucdavis.edu

Jeffrey J. Steiner

USDA-ARS

David D. Myrold

Oregon State University

Follow this and additional works at: https://digitalcommons.unl.edu/usdaarsfacpub

Part of the Agricultural Science Commons

Davis, Jennifer H.; Griffith, Stephen M.; Horwath, William R.; Steiner, Jeffrey J.; and Myrold, David D., "Mitigation of Shallow Groundwater Nitrate in a Poorly Drained Riparian Area and Adjacent Cropland" (2007). Publications from USDA-ARS / UNL Faculty. 264.

https://digitalcommons.unl.edu/usdaarsfacpub/264

This Article is brought to you for free and open access by the U.S. Department of Agriculture: Agricultural Research Service, Lincoln, Nebraska at DigitalCommons@University of Nebraska - Lincoln. It has been accepted for inclusion in Publications from USDA-ARS / UNL Faculty by an authorized administrator of DigitalCommons@University of Nebraska - Lincoln. 


\title{
Mitigation of Shallow Groundwater Nitrate in a Poorly Drained Riparian Area and Adjacent Cropland
}

\author{
Jennifer H. Davis, Stephen M. Griffith,* William R. Horwath, Jeffrey J. Steiner, and David D. Myrold
}

\begin{abstract}
Riparian ecosystems, through their unique position in the agricultural landscape and ability to influence nutrient cycles, can potentially reduce $\mathrm{NO}_{3}$ loading to surface and ground waters. The purpose of this study was to determine the fate of $\mathrm{NO}_{3}$ in shallow groundwater moving along a lateral flowpath from a grass seed cropping system through an undisturbed mixed-species herbaceous riparian area. Soil $\mathbf{A}$ $(30-45 \mathrm{~cm})$ and $\mathrm{C}$ horizon $(135-150 \mathrm{~cm}) \mathrm{NO}_{3}$, dissolved oxygen, and nitrous oxide concentrations were significantly higher in the cropping system than the adjacent riparian area. Nitrate concentrations in both horizons of the riparian soil were consistently at or below $0.05 \mathrm{mg} \mathrm{N} \mathrm{L}^{-1}$ while cropping system concentrations ranged from 1 to $12 \mathrm{mg} \mathrm{N} \mathrm{L}^{-1}$. Chloride data suggested that $\mathrm{NO}_{3}$ dilution occurred from recharge by precipitation. However, a sharp decrease in $\mathrm{NO}_{3} / \mathrm{Cl}$ ratios as water moved into the riparian area indicated that additional dilution of $\mathrm{NO}_{3}$ concentrations was unlikely. Riparian area $\mathbf{A}$ horizon soil water had higher dissolved organic carbon than the cropping system and when the riparian soil became saturated, available electron acceptors $\left(\mathrm{O}_{2}, \mathrm{NO}_{3}\right)$ were rapidly reduced. Dissolved inorganic carbon was significantly higher in the riparian area than the cropping system for both horizons indicating high biological activity. Carbon limitation in the cropping system may have led to microbial respiration using primarily $\mathrm{O}_{2}$ and to a lesser degree $\mathrm{NO}_{3}$. Within $6 \mathrm{~m}$ of the riparian/cropping system transition, $\mathrm{NO}_{3}$ was virtually undetectable.
\end{abstract}

$\mathrm{T}$ HE presence of high $\mathrm{NO}_{3}$ in ground and surface water can, under certain conditions, be associated with agricultural sources including the use of fertilizer $\mathrm{N}$ (Goldstein et al., 1998). Overuse of fertilizer, poor timing of applications, and the temporary nature of the crop sink for $\mathrm{N}$ all contribute to potential excess $\mathrm{NO}_{3}$ in agricultural landscapes (Davis, 2003). On-farm reduction and optimization of fertilizer $\mathrm{N}$ applications are potential remedies for elevated $\mathrm{NO}_{3}$ concentrations in water supplies; however, the relatively low cost of fertilizer $\mathrm{N}$ makes these approaches difficult to justify (Martin et al., 1999). Riparian zones, which can potentially mitigate $\mathrm{NO}_{3}$, are receiving increased interest as alternatives for protecting and improving water quality (Hill, 1996).

The effectiveness of riparian zones at decreasing $\mathrm{NO}_{3}$ concentrations during transport from upland agricultural fields to streams can depend on the extent, management, and type of vegetation as well as the topography and hydrology of the site (Young et al., 1980; Peterjohn and Correll, 1984; Lowrance et al., 1984b; Dillaha et al., 1989;

J.H. Davis, S.M. Griffith, and J.J. Steiner, USDA-ARS, $3450 \mathrm{SW}$ Campus Way, Corvallis, OR 97331. W.R. Horwath, Dep. LAWR, Univ. of California, Davis, CA 95616. D.D. Myrold, Dep. of Crop and Soil Science, Oregon State Univ., Corvallis, OR 97331. Received 10 May 2006. *Corresponding author (griffits@onid.orst.edu).

Published in J. Environ. Qual. 36:628-637 (2007).

Technical Reports: Ground Water Quality

doi:10.2134/jeq2006.0186
Haycock and Pinay, 1993; Groffman et al., 1996; Schnabel et al., 1996; Martin et al., 1999; Wigington et al., 2003). Both biological and physical processes can be responsible for the observed reductions in riparian soil water $\mathrm{NO}_{3}$ concentrations. Biological processes of $\mathrm{NO}_{3}$ removal include immobilization by plants (Peterjohn and Correll, 1984; Haycock and Pinay, 1993) and microbes, denitrification (Jacobs and Gilliam, 1985; Lowrance, 1992), and dissimilatory $\mathrm{NO}_{3}$ reduction to $\mathrm{NH}_{4}$ (DNRA) (Hill, 1996). Denitrification results in the net loss of $\mathrm{N}$ from the ecosystem whereas plant or microbial uptake and DNRA would result in retention. Physical processes include the mixing of water at converging flow paths, divergence of high $\mathrm{NO}_{3}$ groundwater around a dense soil layer, or upwelling of older, low $\mathrm{NO}_{3}$ groundwater (Böhlke et al., 2002; Puckett et al., 2002; Israel et al., 2005). These processes can be misinterpreted as biological consumption of $\mathrm{NO}_{3}$ and loss from the system (Mengis et al., 1998). Dominant processes will affect how and if riparian areas can be managed for $\mathrm{NO}_{3}$ removal. For example, if physical processes dominate, vegetation management (type of vegetation, width of area, etc.) would be a less effective tool in reducing $\mathrm{NO}_{3}$ concentrations.

Most riparian studies have been conducted in the eastern coastal plain of the United States (Hill, 1996). In the Willamette Valley, Oregon, soil and climatic conditions are very different. Nitrate can accumulate in soils during the dry warm summers and then be exported in shallow groundwater during the cool wet winters, sometimes at levels exceeding the EPA limit of $10 \mathrm{ppm}$ $\mathrm{NO}_{3}-\mathrm{N}$ (Davis, 2003).

The primary purpose of this study was to determine the transport and fate of $\mathrm{NO}_{3}$ in the $\mathrm{A}$ and $\mathrm{C}$ soil horizons as water moves from an intensively managed cropping system through an undisturbed mixed-species, herbaceous riparian area. Specifically, we wanted to determine the efficacy of the seasonally saturated riparian area at mitigating shallow groundwater $\mathrm{NO}_{3}$ concentrations and determine underlying biotic and/or physical mechanisms. We also evaluated the contribution of $\mathrm{NO}_{3}$ to the riparian area from the transition of a fourth year perennial ryegrass (Lolium perenne L.) crop to notill clover (Trifolium repens L.) cropping system.

\section{MATERIALS AND METHODS}

\section{Site Description}

Experiments were conducted from fall 1997 through the early summer 1999 on a tributary of Lake Creek in Linn County, Oregon, USA $\left(44^{\circ} 32^{\prime} \mathrm{N}, 123^{\circ} 03^{\prime} \mathrm{W}\right)$ (Fig. 1). The

Abbreviations: DIC, dissolved inorganic carbon; DNRA, dissimilatory nitrate reduction to ammonium; DOC, dissolved organic carbon; $\mathrm{DO}$, dissolved oxygen; ECD, electron capture detector. 

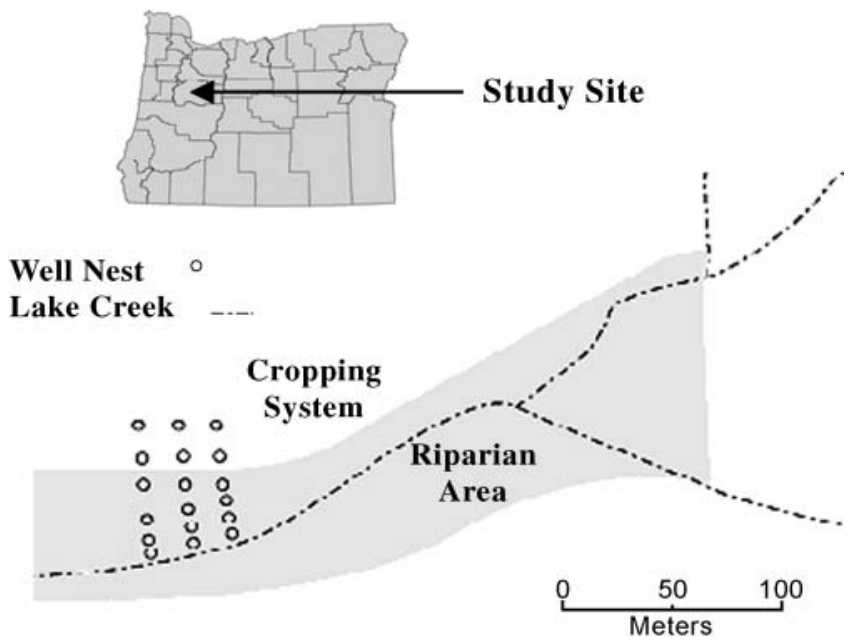

Fig. 1. Location of the study site in Linn County, OR and placement of three transects of wells, running perpendicular to the stream from the cropping system through the riparian area to Lake Creek.

study site consisted of an ephemeral stream bordered on both sides by an uncultivated, herbaceous, mixed species riparian area that buffered the stream from an adjacent intensively managed perennial ryegrass seed production field. Water quality was reported for the site in the previous $2 \mathrm{yr}$ (fall of 1995 to summer 1997) by Wigington et al. (2003). Topography at the Lake Creek site is quite flat, with slopes $<3 \%$ and the dominant soils at the site are poorly drained (Dayton-Holcomb series). Dayton soil series (fine, smectitic, mesic Vertic Albaqualfs) extended from the streambed into the riparian area approximately $25 \mathrm{~m}$. The Holcomb soil series (fine, smectitic, mesic Typic Argialbolls) occupies the upland position extending from the Dayton soil into the cropping system. The presence of a restrictive, clay $\mathrm{IIB}_{\mathrm{t}}$ horizon below the A and $\mathrm{E}$ horizons in Dayton and Holcomb soils results in perched water tables that persist during the wet season (Boersma et al., 1972). These restrictive horizons are underlain by silty clay loam or silt loam IIIC horizons.

The riparian area was 30 to $48 \mathrm{~m}$ wide and vegetated predominantly with grasses and fewer forbs, sedges, and rushes (McAllister et al., 2000). The riparian area had not been cultivated since 1975, although the vegetation was occasionally mowed and removed before 1995. In the fall of 1998, the cropping system started its fourth year in perennial ryegrass seed production and received $173 \mathrm{~kg} \mathrm{~N}^{-1}$ as a urea-ammonium sulfate solution in split spring applications (3 Mar. 1998 and 11 Apr. 1998). In September 1998, the ryegrass seed crop was sprayed with glyphosate and direct seeded with clover. Vigorous plant growth of the clover did not begin until April 1999 , leaving the soil essentially barren during the fall, winter, and early spring. The clover crop received $90 \mathrm{~kg} \mathrm{~N} \mathrm{ha}^{-1}$ as urea in spring 1999.

Total annual precipitation was $1524 \mathrm{~mm}$ in 1998 and $1265 \mathrm{~mm}$ in 1999, 93\% of which occurred between November and June (Hyslop Field Station, Benton County, OR; $44^{\circ} 38^{\prime} \mathrm{N}, 123^{\circ} 11^{\prime} \mathrm{W}$ ) (Oregon Climate Service, 2005). More importantly, total precipitation for water year 1997-1998 (Sept. 1997 to Sept. 1998) was $1250 \mathrm{~mm}$ and water year 1998-1999 (Sept. 1997 to Sept. 1998) was $1518 \mathrm{~mm}$. As usual for this region's marine climate, little precipitation occurred from June to October both years; thus the soil became dry and cracked and the water table dropped below $1.5 \mathrm{~m}$ during these periods. Consistent seasonal precipitation began in October and stream flow started in November (Wigington et al., 2003).
During the wet winter (November to February), the water tables remained close to the soil surface and soils of both the riparian area and cropping system were saturated. As spring precipitation decreased, water tables fluctuated, and wet/dry cycles occurred in the surface soils. Data from Wigington et al. (2003) indicated that when soils were saturated, water moved through the soil along a downslope hydraulic gradient through these poorly drained soils from the upland cropping system through the riparian area to the stream. Only a small proportion of stream flow came from this flow path. Most stream water originated from overland flow through ephemeral swales in the grass seed cropping system.

\section{Sample Collection}

In 1997, three transects of closed-headspace sampling wells, approximately $17.5 \mathrm{~m}$ apart, were installed perpendicular to the stream (Fig. 1). Each transect consisted of six sampling points. At each sampling point (well nest), a pair of wells were installed to collect water from the A horizon $(30-45 \mathrm{~cm})$ and the C horizon (135-150 cm). Rows of well nests ran parallel to the stream. Two rows were in the Dayton soil of the riparian area ( 0.5 and $8-9 \mathrm{~m}$ from the stream), the riparian area with Holcomb soil (15-17 and 24-32 $\mathrm{m}$ from the stream), and the cropping system with Holcomb soil (36-44 and 51-58 m from the stream). Closed-headspace sampling wells were installed $1 \mathrm{~m}$ from existing open headspace wells (Wigington et al., 2003). The closed headspace wells (Fig. 2) containing Argon allowed sampling of soil water, under low redox conditions, that had not been exposed to the atmosphere. These wells have been shown to contain lower, probably more realistic concentrations of $\mathrm{NO}_{3}$ (Baham et al., 1999) and also permitted the sampling of dissolved gases. The sampling wells consisted of

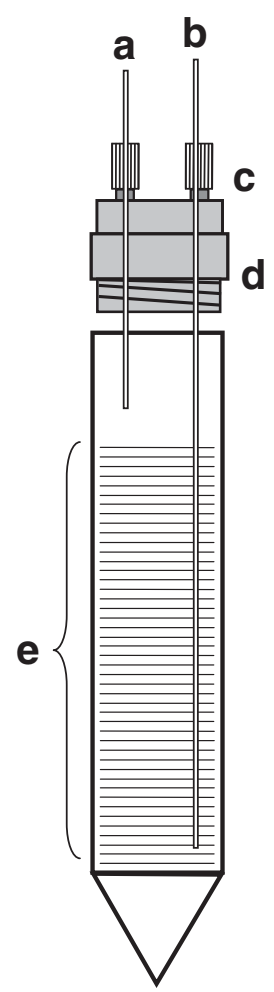

Fig. 2. Closed-headspace well showing (a) inlet for the introduction of Argon gas, (b) water sample collection tube, (c) plastic compression fitting, (d) screw top to well, (e) $15 \mathrm{~cm}$ screening (Baham et al., 1999). 
$5.1 \mathrm{~cm}$ i.d. PVC pipes with a slot width of $0.25 \mathrm{~mm}$ and a slotscreening interval of $15 \mathrm{~cm}$. The tops of the sampling wells were sealed except for two lengths of $3.2 \mathrm{~mm}$ o.d. Teflon tubing extending from the well bottom to the soil surface. In the fall of 1998, three pairs (A and C horizon) of open-headspace piezometers were installed on the center transect equidistant between the last row of riparian wells and first row of cropping system wells, the central pair being located on the riparian/ cropping system border.

When water was present, samples were collected weekly from November 1997 to June 1998 (water year 1997/1998) and November 1998 to May 1999 (water year 1998/1999), alternating weekly between the $\mathrm{A}$ and $\mathrm{C}$ horizon. Before sampling, three well volumes were removed with a stainless steel hand pump. During sampling, the vent tube (Fig. 2) was connected to an inner tube containing high-grade argon gas. Samples to be analyzed for $\mathrm{NO}_{3}$, dissolved organic carbon (DOC), and $\mathrm{Cl}$ were collected directly into an open $250 \mathrm{~mL}$ amber glass bottle. After this sample was collected, a septum was placed on the sample tube and a $50-\mathrm{mL}$ volume of water was drawn into a syringe and discarded. Another $40 \mathrm{~mL}$ of water was immediately collected and injected into a $12-\mathrm{mL}$ vial whose headspace had been evacuated and flushed with high-grade helium several times. Two volumes of water were flushed through the vial before a sample was kept. This procedure was repeated with a $20-\mathrm{mL}$ vial. Water from the $12-\mathrm{mL}$ vials was analyzed for dissolved oxygen (DO) using Chemet kits K-7501 (detection limit: $0.025 \mathrm{mg} \mathrm{O}_{2} \mathrm{~L}^{-1}$ ) and $\mathrm{K}-7512$ (detection limit: $1 \mathrm{mg} \mathrm{O}_{2} \mathrm{~L}^{-1}$ ) (CHEMetrics, Inc., Calverton, VA) and dissolved inorganic C (DIC) using the Dohrman DC-190 total organic carbon analyzer (detection limit: $0.1 \mathrm{mg} \mathrm{C} \mathrm{L}^{-1}$ ) (TekmarDohrman, Cincinnati, OH). Water from the 20-mL vials was analyzed for dissolved $\mathrm{N}_{2} \mathrm{O}$. In the laboratory, $8 \mathrm{~mL}$ of water were removed and simultaneously replaced with high-grade helium. The remaining $12 \mathrm{~mL}$ were incubated at $25^{\circ} \mathrm{C}$ for $1 \mathrm{~h}$ to allow for headspace equilibration before gas samples were removed for analysis of $\mathrm{N}_{2} \mathrm{O}$ on an HP6890 GC equipped with a ${ }^{63} \mathrm{Ni}$ ECD (detection limit: $0.9 \mu \mathrm{g} \mathrm{N} \mathrm{L}{ }^{-1}$ ) (Agilent Technologies, Inc., Palo Alto, CA).

Samples collected for $\mathrm{NO}_{3}$ and DOC analyses were filtered through $0.45-\mu \mathrm{m}$ polycarbonate filters. Filters were washed before use by soaking in a sequence of two double-deionized water baths for a minimum of $24 \mathrm{~h}$. Analyzing sample blanks validated the filter washing procedure. DOC was quantified by high temperature catalytic combustion on the Dohrman DC-190 total carbon analyzer (detection limit: $0.1 \mathrm{mg} \mathrm{C} \mathrm{L}^{-1}$ ) (Tekmar-Dohrman, Cincinnati, OH). Soil $\mathrm{NO}_{3}$ was determined colorimetrically using QuikChem method 10-107-04-1$\mathrm{A}\left(\mathrm{NO}_{3}-\mathrm{N}\right)$ (detection limit: $\left.0.05 \mathrm{mg} \mathrm{N} \mathrm{L}^{-1}\right)$ on a flow injection autoanalyzer (Lachat Instruments, Milwaukee, WI).

Water samples collected in 1998-1999 were filtered and analyzed as described above in addition to being analyzed colorimetrically for $\mathrm{Cl}$ using QuikChem method 10-117-07-1-C

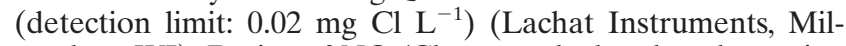
waukee, WI). Ratios of $\mathrm{NO}_{3} / \mathrm{Cl}$ were calculated to determine if $\mathrm{NO}_{3}$ disappearance was due to either biological or physical phenomena (Gast et al., 1974; Lowrance et al., 1984a; Martin et al., 1999). Chloride served as a conservative tracer for $\mathrm{NO}_{3}$ because they are transported similarly, but $\mathrm{Cl}$ is biologically inactive. Along a hydrologic flowpath, if $\mathrm{NO}_{3}$ concentrations decline and $\mathrm{Cl}$ concentrations stay constant, then $\mathrm{NO}_{3}$ was likely removed biologically. If $\mathrm{Cl}$ concentrations change in tandem with $\mathrm{NO}_{3}$ concentrations, then the decline in $\mathrm{NO}_{3}$ concentrations is most likely due to either a dilution from low $\mathrm{NO}_{3}$ groundwater (Mengis et al., 1998) or stream water (Pinay and DeCamps, 1988), or to a divergence of the flow path (Cey et al., 1999).

\section{Data Analysis}

Differences in means between the sites (cropping system vs. riparian area) and depths (A vs. C horizon) were determined by analysis of variance using a modified split-plot design, with site as the main plot and depth as subplots using SPSS statistical software (SPSS Inc., 2002). The model for this design was:

$$
\begin{aligned}
y_{\mathrm{ijkl}}= & \mu+S_{\mathrm{i}}+B_{\mathrm{j}}+S B_{\mathrm{ij}}+\delta_{(\mathrm{ij})}+T_{\mathrm{k}}+S T_{\mathrm{ik}}+S B T_{\mathrm{iJk}} \\
& +\varepsilon_{(\mathrm{ijk})}
\end{aligned}
$$

where $S$ is site, $B$ is block, and $T$ is depth. The restrictions on randomization were represented by: $\delta_{(\mathrm{ij})}$ the restriction error. The mean square (MS) for $S B$ was used to test $S$ main effect, and the MS for $S B T$ used to test the $T$ main effects and $S T$ interaction. Means separations were done using Fisher's Protected Least Significant Difference test (Sokal and Rohlf, 1981). Data were not transformed. All differences were significant at $p \leq 0.001$, unless otherwise stated.

\section{RESULTS \\ Nitrate}

Soil pore water $\mathrm{NO}_{3}$ concentrations from closedheadspace wells were significantly $(p \leq 0.001)$ higher in the cropping system than the riparian area for $\mathrm{A}$ $(30-45 \mathrm{~cm})$ and $C$ horizons $(135-150 \mathrm{~cm})$ both years (Fig. 3). Significance of main effects and interactions are shown in Table 1. Mean $\mathrm{A}$ and $\mathrm{C}$ horizon soil water $\mathrm{NO}_{3}$ concentrations in the riparian area were consistently low $\left(\leq 0.05 \mathrm{mg} \mathrm{NO}_{3}-\mathrm{N} \mathrm{L}^{-1}\right)$. The mean and standard error of $\mathrm{NO}_{3}$ concentrations in the $\mathrm{A}$ horizon of the cropping system (years pooled) were $4.19 \pm$ $0.18 \mathrm{mg} \mathrm{NO}_{3}-\mathrm{N} \mathrm{L}^{-1}$ and in the $\mathrm{C}$ horizon were $5.62 \pm$ $0.13 \mathrm{mg} \mathrm{NO}_{3}-\mathrm{N} \mathrm{L}^{-1}$. Data collected in 1998-1999 from

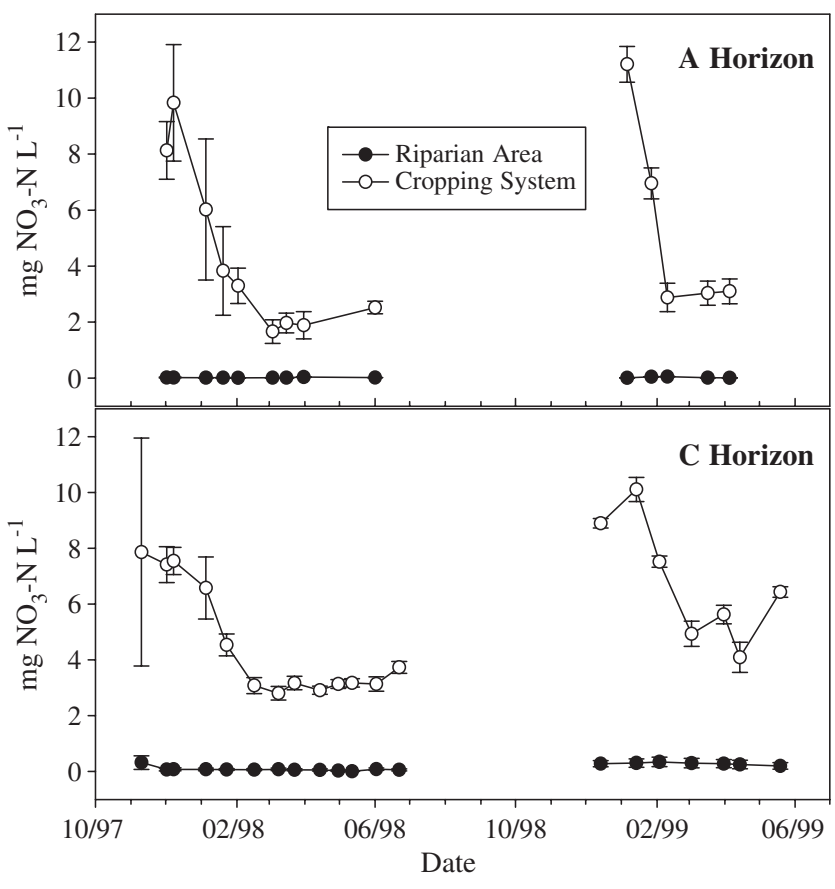

Fig. 3. Mean and standard error of nitrate concentrations in the soil pore water of the $A$ and $C$ horizons of the riparian area and cropping system. 
Table 1. Statistical summary of main effects and interactions of site and depth. $\dagger$

\begin{tabular}{lcccccc}
\hline Parameter & $\mathbf{N O}_{\mathbf{3}}$ & DOC & $\mathbf{N}_{\mathbf{2}} \mathbf{O}$ & DO & DIC & $\mathbf{C I}$ \\
\hline Site & $* * *$ & $* * *$ & $* * *$ & $* * *$ & $* * *$ & $\mathbf{n s} \S$ \\
Depth & $* * *$ & $* * *$ & $* * *$ & $* * *$ & $* * *$ & $* * *$ \\
Site $\times$ depth & $* * *$ & $* * *$ & $* * *$ & $* * *$ & $\mathbf{n s}$ & $* * *$ \\
\hline
\end{tabular}

$* * * \boldsymbol{p}=\mathbf{0 . 0 0 1}$.

$\uparrow$ DOC, dissolved organic carbon; DO, dissolved oxygen; DIC, dissolved inorganic carbon.

$\S$ ns, $p>0.05$.

three evenly spaced, open-headspace piezometers placed between the fourth (riparian) and fifth (cropping system) rows showed that in the A horizon, $\mathrm{NO}_{3}$ concentrations dropped immediately within the transition zone (Fig. 4). In the $\mathrm{C}$ horizon, there was a more gradual decrease in $\mathrm{NO}_{3}$ concentrations as water moved from the cropping system into the riparian area. In the cropping system, $\mathrm{A}$ and $\mathrm{C}$ horizon $\mathrm{NO}_{3}$ concentrations were highest after fall wet-up and decreased over the water year (Fig. 3). Elevated $\mathrm{NO}_{3}$ concentrations after fall wet-up were most likely due to the movement of mineralized and nitrified $\mathrm{N}$ that accumulated in the soil over the warm, dry summer (Nelson et al., 2006). Higher $\mathrm{C}$ horizon soil water $\mathrm{NO}_{3}$ reflected movement of $\mathrm{NO}_{3}$ below the root zone and the reduced biological activity of subsoils (Böhlke and Denver, 1995).

Cropping system $\mathrm{NO}_{3}$ concentrations were significantly higher in $1998-1999\left(6.66 \pm 0.17 \mathrm{mg} \mathrm{NO}_{3}-\mathrm{N} \mathrm{L}^{-1}\right)$

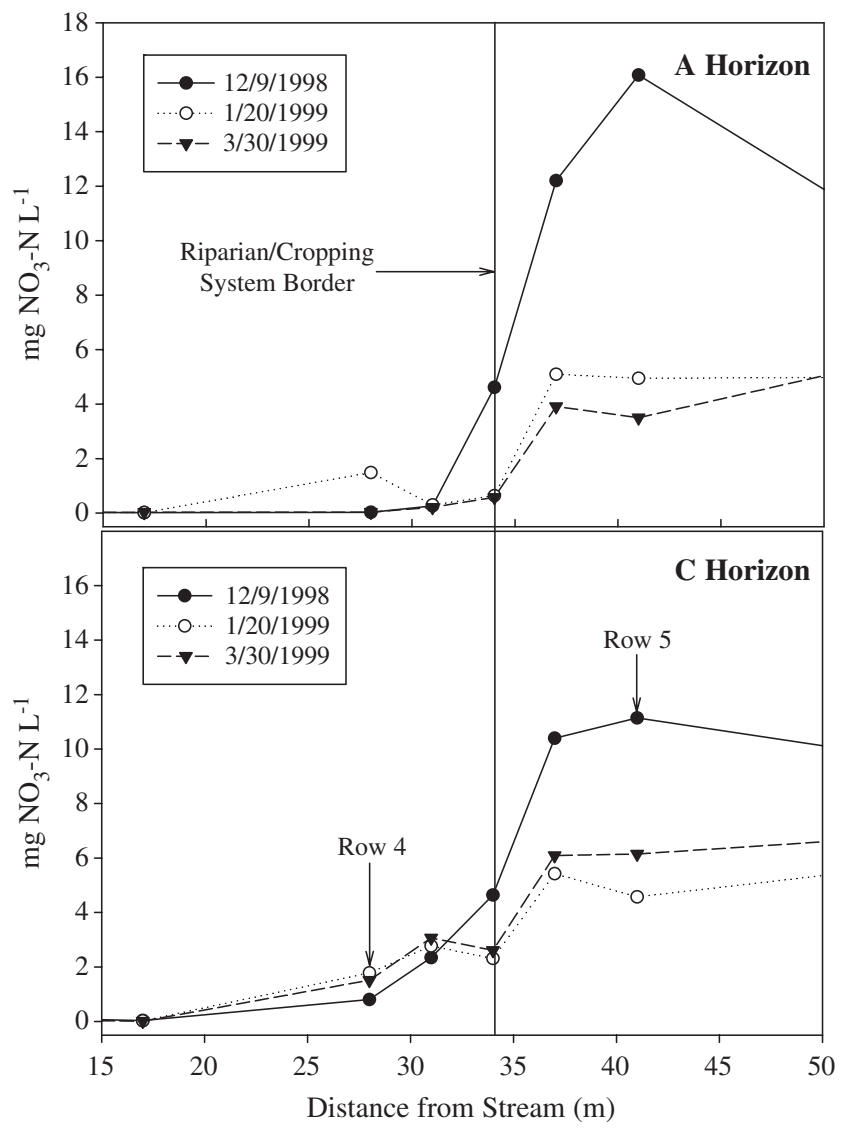

Fig. 4. Nitrate concentrations in open-headspace wells installed in the fall of 1998 between rows 4 (riparian) and 5 (cropping system) on the center transect. (first-year clover crop) than 1997-1998 (3.15 $\pm 0.15 \mathrm{mg}$ $\mathrm{NO}_{3}-\mathrm{N} \mathrm{L}^{-1}$ ) (fourth year perennial ryegrass seed crop). Differences most likely resulted from the transition to a new crop in the fall of 1998. The clover planting was sparsely established with no more than a few leaves per plant present until April the following spring.

\section{Chloride}

Unlike $\mathrm{NO}_{3}, \mathrm{Cl}$ concentrations were not significantly different between the riparian area and cropping system (Table 1). A horizon soil water showed a consistent decrease in Cl concentrations over the 1998-1999 water year (Fig. 5). The decrease in $\mathrm{Cl}$ coincided with the decrease seen in cropping system $\mathrm{NO}_{3}$, where concentrations decreased until April and then remained relatively constant until June (Fig. 3). The percentage drop from January to April in $\mathrm{NO}_{3}(73 \pm 2.9 \%)$ was higher than $\mathrm{Cl}$ $(51 \pm 6.4 \%)$. These data suggested that dilution of $\mathrm{A}$ horizon soil water $\mathrm{Cl}$ and $\mathrm{NO}_{3}$ occurred through inputs of precipitation but that biological consumption of $\mathrm{NO}_{3}$ also occurred, further decreasing concentrations. $\mathrm{C}$ horizon $\mathrm{Cl}$ concentrations also decreased over the water year by $29 \%( \pm 6.0 \%)$, suggesting that dilution by recharge was also occurring in the $\mathrm{C}$ horizon. However, a greater decrease in cropping system $\mathrm{NO}_{3}$ concentrations $(60 \pm 4.5 \%)$ again suggested that biological processes were also responsible for reducing $\mathrm{NO}_{3}$ concentrations.

Spatial patterns of $\mathrm{NO}_{3} / \mathrm{Cl}$ ratios can indicate the relative importance of biological consumption and dilution of $\mathrm{NO}_{3}$ along the hydrologic flow path (Gast et al., 1974; Lowrance et al., 1984a). Martin et al. (1999) and Lowrance (1992) studied $\mathrm{NO}_{3}$ dynamics in grass and wooded riparian areas and, based on decreases in the $\mathrm{NO}_{3} / \mathrm{Cl}$ ratio within the riparian area, concluded that biological consumption was primarily responsible for decreased riparian $\mathrm{NO}_{3}$ concentrations. Nitrate/Cl ratios (Table 2) in the A and C horizons at Lake Creek showed a dramatic and consistent decrease in $\mathrm{NO}_{3}$ relative to $\mathrm{Cl}$, as water moved into the riparian area. Nitrate was consistently low throughout the riparian area, whereas $\mathrm{Cl}$ remained relatively high. This trend was consistent

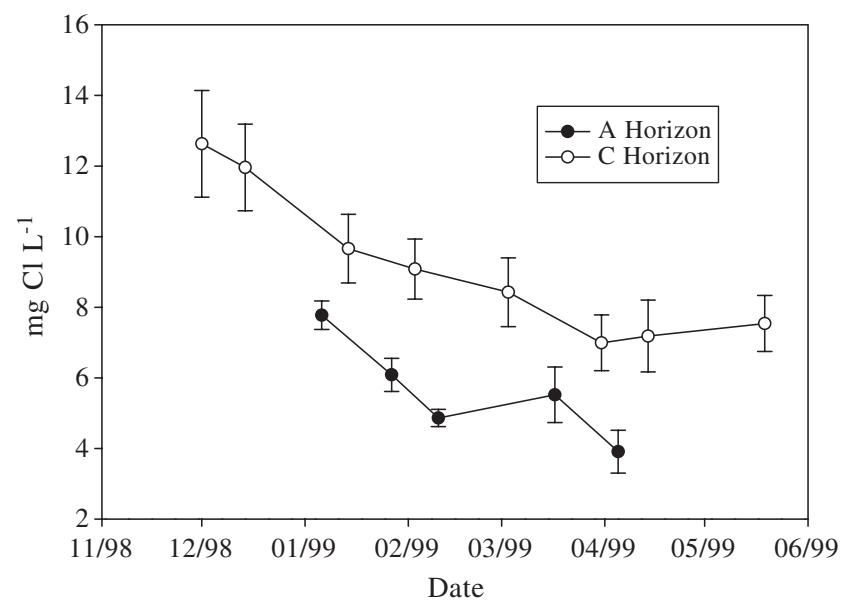

Fig. 5. Mean and standard error of chloride concentrations in the soil pore water of the A and C horizons during water year 1998-1999. 
Table 2. Mean and standard error of nitrate/chloride ratios ( $\mathrm{mg} \mathrm{N} \mathrm{L} \mathrm{N}^{-1} / \mathrm{mg} \mathrm{Cl} \mathrm{L}^{-1}$ ) in the riparian area (RA) and the cropping system (CS) for water year 1998-1999 in the A and C horizons.

\begin{tabular}{|c|c|c|c|}
\hline Distance from stream & Area & $\begin{array}{l}\text { A Horizon } \\
(30-45 \mathrm{~cm})\end{array}$ & $\begin{array}{c}\text { C Horizon } \\
(135-150 \mathrm{~cm})\end{array}$ \\
\hline $\mathbf{m}$ & & & \\
\hline 0.5 & RA & $0.01(0.00)$ & $0.02(0.01)$ \\
\hline 9 & RA & $0.01(0.00)$ & $0.01(0.00)$ \\
\hline 17 & RA & $0.01(0.00)$ & $0.01(0.00)$ \\
\hline 28 & RA & $0.01(0.00)$ & $0.17(0.02)$ \\
\hline 41 & CS & 0.79 (0.11) & $1.1(0.07)$ \\
\hline 55 & CS & $0.82(0.11)$ & $1.1(0.07)$ \\
\hline
\end{tabular}

with biological consumption of $\mathrm{NO}_{3}$ along the flow path as opposed to dilution from a converging or diverging flow path.

\section{Dissolved Organic Carbon}

Soluble organic $\mathrm{C}$ is one potential source of energy for microbes and has been used as an indicator of the potential for biological activity in the soil profile, particularly for denitrification (Meek et al., 1970). Opposite of temporal $\mathrm{NO}_{3}$ trends, DOC concentrations (depths pooled) were higher in 1997-1998 than 1998-1999 for the cropping system and especially the riparian area (Fig. 6). Greater rainfall in the summer of 1997 (189 mm in June, July, and August) than the summer of 1998 (50 mm) (Oregon Climate Service, 2005), may have increased wet-dry cycles, enhancing organic matter decomposition, leading to higher dissolved $\mathrm{C}$ concentrations (Reddy and Patrick, 1975; Aulakh et al., 1992). Mean A horizon concentrations in 1997-1998 were $13.3 \mathrm{mg} \mathrm{C} \mathrm{L}^{-1}$ in the riparian area and $6.61 \mathrm{mg} \mathrm{C} \mathrm{L}^{-1}$ in the cropping

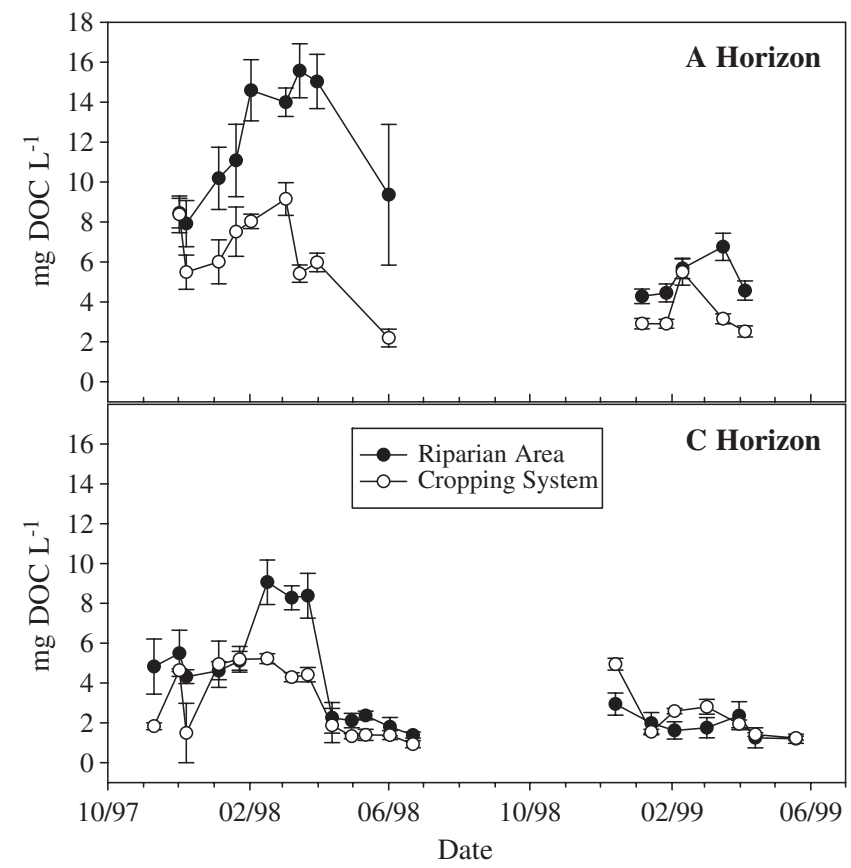

Fig. 6. Mean and standard error of dissolved organic carbon (DOC) concentrations in the soil pore water of the $\mathrm{A}$ and $\mathrm{C}$ horizons of the riparian area and cropping system. system compared with $5.14 \mathrm{mg} \mathrm{C} \mathrm{L}^{-1}$ in the riparian area and $3.25 \mathrm{mg} \mathrm{C} \mathrm{L}^{-1}$ in the cropping system in 1998-1999.

Spatial trends in A horizon DOC were also opposite of $\mathrm{NO}_{3}$, with significantly higher $\mathrm{DOC}$ in the riparian than the cropping system for both years. Higher riparian DOC most likely reflected permanent vegetation (larger root biomass) (Tufekcioglu et al., 1999) and lack of soil disturbance (Balesdent et al., 1990). In the C horizon, there was no difference in DOC concentrations between the riparian area and cropping system and annual mean DOC concentrations were all below $5 \mathrm{mg} \mathrm{C} \mathrm{L}^{-1}$. Although mean annual $\mathrm{C}$ horizon DOC concentrations were in the range to limit denitrification, point concentrations in the riparian area reached $14 \mathrm{mg} \mathrm{C} \mathrm{L}^{-1}$ before decreasing in late spring. The DOC concentrations in the riparian area were higher in the $\mathrm{A}$ than the $\mathrm{C}$ horizon. We hypothesized that the riparian surface soils had higher levels of DOC from the decomposition of plant residues, building and degrading of soil organic matter, and the release of root exudates. DOC concentrations in the cropping system were similar between the $\mathrm{A}$ and $\mathrm{C}$ horizons.

In 1997-1998, A horizon DOC concentrations gradually increased until March and then decreased between March and June (Fig. 6). As DOC concentrations increased, $\mathrm{NO}_{3}$ and $\mathrm{Cl}$ concentrations decreased from dilution by precipitation and presumably biological consumption of $\mathrm{NO}_{3}$. The infiltration of precipitation may have transported DOC from the surface down into the soil profile, increasing concentrations at $30-$ to $45-\mathrm{cm}$ depth over the fall and winter. The $\mathrm{C}$ horizon had a similar but delayed increase in DOC but also had a dramatic decrease around the same time as in the A horizon. A horizon DOC concentrations in the second year (1998-1999) started out low, similar to those of the previous spring, increased slightly in early spring and then decreased. In 1998-1999, C horizon DOC concentrations decreased from December to January and remained consistently low for the rest of the water year. The smaller pulse of DOC in 1998-1999 may reflect potentially less organic $\mathrm{C}$ mineralization in the dry summer of 1998 compared with 1997.

\section{Dissolved Oxygen}

Dissolved oxygen, the electron acceptor that yields the most energy for microbial respiration, can be an indicator of potential $\mathrm{NO}_{3}$ reduction through denitrification or DNRA. A and C horizon soil water DO concentrations, measured in 1998-1999, had temporal and spatial patterns similar to $\mathrm{NO}_{3}$ (Fig. 7). A horizon DO generally decreased over the sampling season and was higher in the cropping system than the riparian area $(p \leq 0.001)$. The DO concentrations inside the riparian area were generally $<1.0 \mathrm{mg} \mathrm{O} \mathrm{L}^{-1}$ except in wells next to the stream where concentrations were 2.5 to $6 \mathrm{mg} \mathrm{O} \mathrm{L}^{-1}$. Water in the A horizon sampling wells next to the stream mixes with well-aerated stream water (Wigington et al., 2003). A horizon riparian area DO was low by January and temporal changes were minor. A horizon DO in the cropping system started out higher 


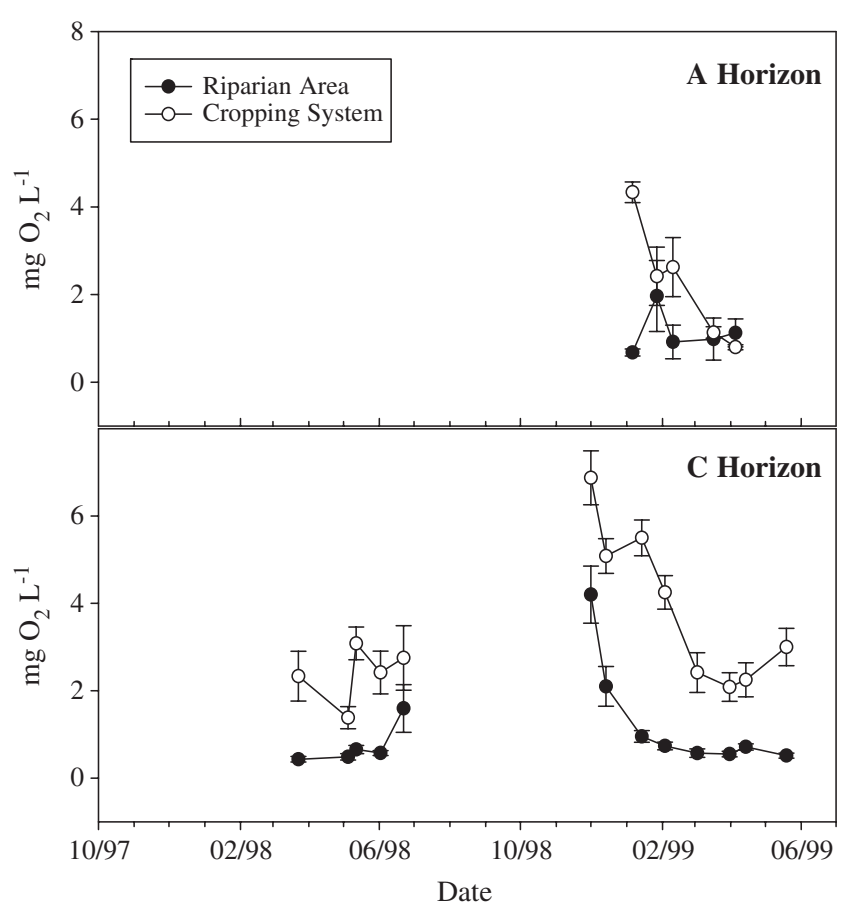

Fig. 7. Mean and standard error of dissolved oxygen concentrations in the soil pore water of the $A$ and $C$ horizons of the riparian area and cropping system.

but dropped by $3.7 \mathrm{mg} \mathrm{L}^{-1}$ from January to April. This decrease was not the result of dilution by precipitation because water entering the soil profile would have had approximately $11 \mathrm{mg} \mathrm{O} \mathrm{L}^{-1}$ (equilibrium with the atmosphere at $10^{\circ} \mathrm{C}$ ) (Weiss, 1970).

Spatial and temporal patterns for $\mathrm{C}$ horizon soil water DO were similar to those of the A horizon, with two exceptions. In January 1999, DO concentrations were lower in A horizon than $\mathrm{C}$ horizon wells presumably from higher biological activity and $\mathrm{O}_{2}$ consumption. A second difference between $\mathrm{A}$ and $\mathrm{C}$ horizon $\mathrm{DO}$ was low concentrations $\left(0.9 \mathrm{mg} \mathrm{O} \mathrm{O}_{2} \mathrm{~L}^{-1}\right)$ in the $\mathrm{C}$ horizon wells closest to the stream where there was less mixing with stream water. Otherwise, $\mathrm{C}$ horizon DO concentrations were spatially similar to $\mathrm{NO}_{3}$ wherein DO dropped significantly as water moved from the cropping system into the riparian area $(p \leq 0.02)$. C Horizon DO was relatively high in December 1998 but by January, concentrations dropped significantly in the riparian area to below $1 \mathrm{mg} \mathrm{O}_{2} \mathrm{~L}^{-1}$ and remained low through late spring. Cropping system DO in the $\mathrm{C}$ horizon decreased gradually until April and then increased in May and June. The same pattern was seen in limited data collected in 1997-1998. Increased late spring DO was most likely from the start of wet/dry cycles in the surface soils. The riparian area maintained low DO conditions but the cropping system did not.

\section{Dissolved Nitrous Oxide}

Nitrous oxide, an intermediate product of denitrification, followed spatial patterns similar to $\mathrm{NO}_{3}$ (Fig. 8). There was more $\mathrm{NO}_{3}$ and $\mathrm{N}_{2} \mathrm{O}$ in the cropping system

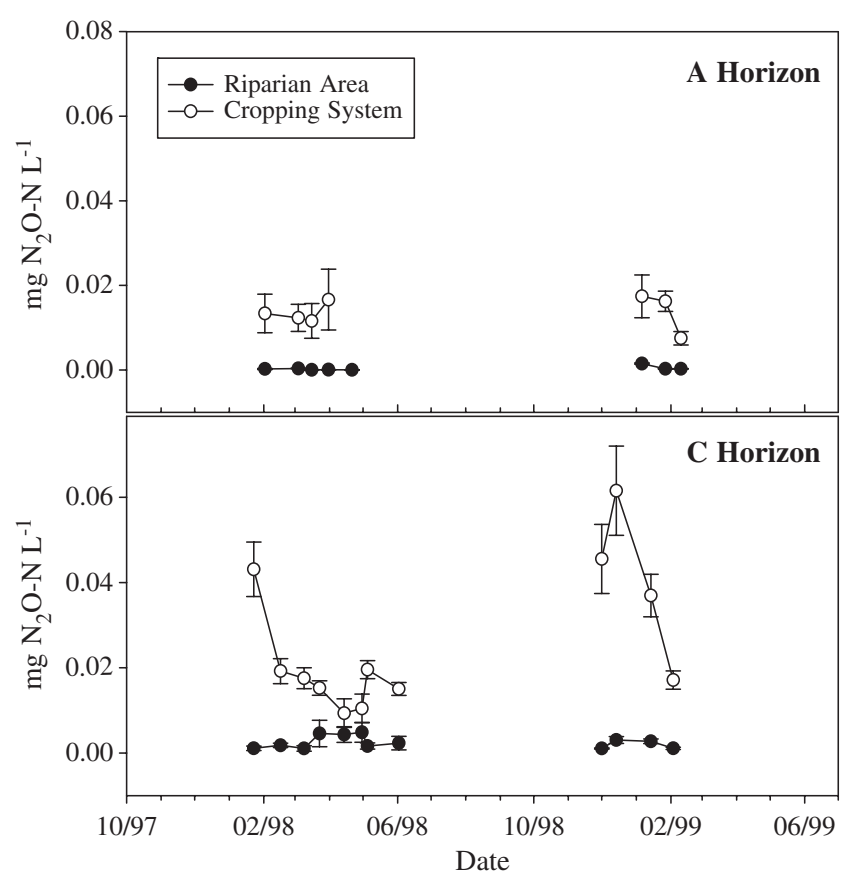

Fig. 8. Mean and standard error of dissolved nitrous oxide concentrations in the soil pore water of the $A$ and $C$ horizons of the riparian area and cropping system.

than in the riparian area for both $\mathrm{A}$ and $\mathrm{C}$ horizon soil water in both years of the study. Nitrous oxide in soil water containing relatively high $\mathrm{NO}_{3}$ provided indirect evidence that denitrification was a potential mechanism of $\mathrm{NO}_{3}$ reduction.

\section{Inorganic Carbon}

Dissolved inorganic carbon (DIC), a byproduct of organic matter oxidation, can be indicative of biological activity in soils. Dissolved inorganic carbon was significantly higher in the riparian area than the cropping system for both horizons (Fig. 9). A horizon DIC concentrations increased over the spring presumably from increased activity with soil warming with the increase being much greater in the riparian area. Dissolved inorganic carbon in the $\mathrm{C}$ horizon also increased in the riparian soil in the spring while the cropping system did not. Although DIC could come from the dissolution of carbonates in the riparian area, the seasonal and spatial trends in DIC in combination with trends in $\mathrm{NO}_{3}$, $\mathrm{DO}$, and DOC indicate that the oxidation of organic $\mathrm{C}$ to support microbial respiration is occurring, especially in the riparian soil.

\section{DISCUSSION}

Higher $\mathrm{NO}_{3}$ concentrations in cultivated compared with riparian shallow groundwater, have been well documented (Lowrance et al., 1984b; Verchot et al., 1997; Mengis et al., 1998). Differences have been attributed to biological processes (Peterjohn and Correll, 1984; Lowrance et al., 1984b; Jacobs and Gilliam, 1985; Haycock and Pinay, 1993), hydrological processes (Böhlke 


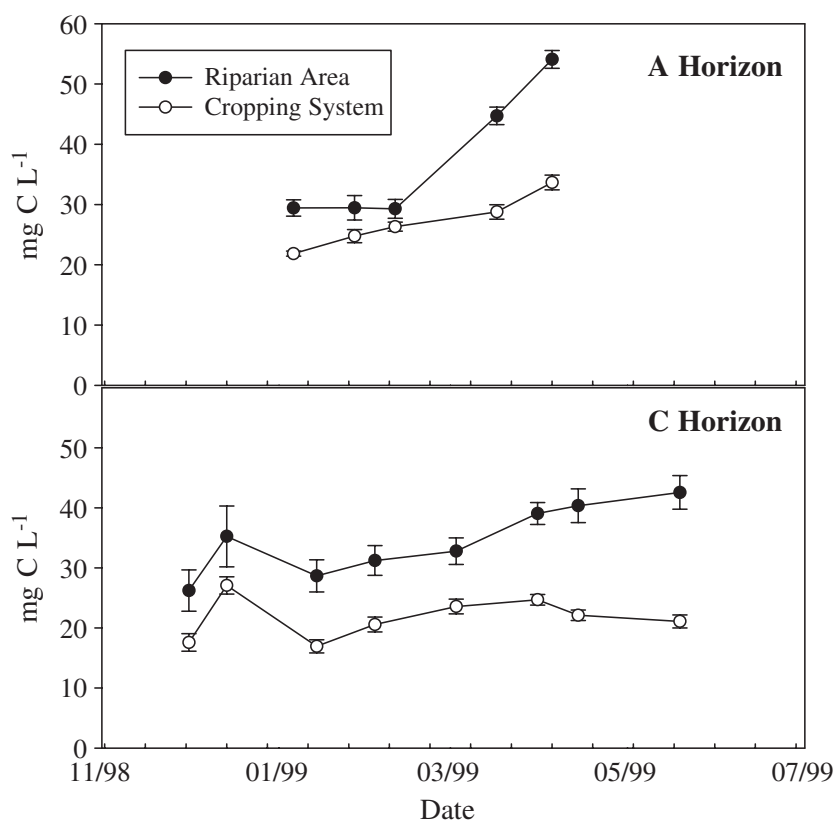

Fig. 9. Mean and standard error of dissolved inorganic carbon concentrations in the soil pore water of the $A$ and $C$ horizons of the riparian area and cropping system.

et al., 2002; Puckett et al., 2002), or both (Israel et al., 2005). At the Lake Creek site, the hydraulic gradient implied flow paths from the cropping system, through the riparian area, to the stream (Wigington et al., 2003). Greater piezometric head in deeper wells than in surface water can indicate discharge of and dilution by deeper groundwater (Böhlke et al., 2002; Puckett and Hughes, 2005). Head measurements made in open piezometers in the $\mathrm{C}$ horizon at the Lake Creek site did not indicate upwelling of deeper groundwater (Wigington et al., 2003). In addition, the dramatic and consistent decrease in $\mathrm{NO}_{3}$ relative to $\mathrm{Cl}$ concentrations as water moved into the riparian area provided additional evidence that dilution from a converging or diverging flow path was not a major factor contributing to low riparian $\mathrm{NO}_{3}$, suggesting $\mathrm{NO}_{3}$ removal during transport. Decreases in both $\mathrm{Cl}$ and $\mathrm{NO}_{3}$ concentrations in the cropping system over the water year suggested dilution from recharge; however, greater decreases in $\mathrm{NO}_{3}$ concentrations in relation to $\mathrm{Cl}$ in the cropping system pointed to additional reduction in $\mathrm{NO}_{3}$ concentrations from biological consumption as well. Plant uptake has been shown to be a significant sink for $\mathrm{NO}_{3}$ in the $\mathrm{A}$ horizon of both the riparian area and cropping system (perennial ryegrass) especially in late spring with the significant growth and $\mathrm{N}$ uptake of grass species (Davis et al., 2006). In the winter, during fallow periods, and below the root zone, microbial processes are responsible for the bulk of reductions in $\mathrm{NO}_{3}$ concentrations.

The riparian area and cropping system are two distinct systems connected by lateral water flow. Consistently low riparian $\mathrm{NO}_{3}$ concentrations are a reflection not only of the lack of direct fertilizer applications but to the ability of the riparian soils to process $\mathrm{NO}_{3}$. In 1997-1998, although riparian DOC concentrations were higher than in the cropping system, both areas were above the 2 to $5 \mathrm{mg} \mathrm{C} \mathrm{L}{ }^{-1}$ range found to limit denitrification in groundwater microcosms (Groffman et al., 1996) and more in line with groundwater DOC concentrations of Israel et al. (2005) (12 to $14 \mathrm{mg} \mathrm{C} \mathrm{L}^{-1}$ ) where denitrification was thought to have led to low riparian $\mathrm{NO}_{3}$ groundwater concentrations in one transect of wells. When the soil at the Lake Creek site became saturated in the fall, available $\mathrm{O}_{2}$ in the riparian area was most likely consumed through microbial and root respiration (A horizon), as evinced by concomitant increases in DIC, creating a strong redox gradient between the riparian area and cropping system. Dissolved oxygen concentrations were sufficiently low $\left(<2 \mathrm{mg} \mathrm{O}_{2} \mathrm{~L}^{-1}\right)$ to then promote respiration using $\mathrm{NO}_{3}$ as an electron acceptor (Gillham, 1991; Cey et al., 1999). In addition, Baham et al. (1999) showed evidence of Fe and Mn reduction in the riparian soil with maximum reduction occurring at a soil depth of 10 to $20 \mathrm{~cm}$. Baham et al. (1999) also found that shallow groundwater of the riparian area contained higher concentrations of Fe(II) and $\mathrm{Mn}(\mathrm{II})$ than the cropping system with peak concentrations in the spring reaching $1500 \mu M \mathrm{Fe}(\mathrm{II})$ and $150 \mu M \mathrm{Mn}(\mathrm{II})$. Denitrification is not dependant solely on the availability of organic $\mathrm{C}$ as an electron donor; reduced inorganic $\mathrm{Fe}, \mathrm{Mn}$, and $\mathrm{S}$ can also supply electrons for $\mathrm{NO}_{3}$ reduction (Korom, 1992; Tesoriero et al., 2000). Upon entering the $\mathrm{Fe}$ - and $\mathrm{Mn}$-reducing riparian area, $\mathrm{NO}_{3}$ in incoming groundwater would likely be reduced through autotrophic and/or heterotrophic denitrification (Korom, 1992). It is also likely that labile organic C in the solid phase provided electrons for microbial respiration (Tesoriero et al., 2000; Puckett et al., 2002). The availability of reduced Fe and Mn (Baham et al., 1999) and other forms of organic $C$ could account for the sustained reduction in $\mathrm{NO}_{3}$ concentrations within the riparian area when DOC concentrations were low, such as in water year 1998-1999 and in the subsoil. A similar upstream site on Lake Creek, which did not have a naturally vegetated riparian area (cropped to stream edge), was found to be more frequently flooded than our riparian site, but was also found to have higher redox values and higher $\mathrm{NO}_{3}$ concentrations (Wigington et al., 2003). The effect the riparian area had on water quality (low $\mathrm{NO}_{3}$ concentrations) was not due only to the proximity of the riparian area to the stream but to whole ecosystem dynamics.

The cropping system had lower DOC and higher $\mathrm{NO}_{3}$ and $\mathrm{DO}$ than the riparian area most likely from periodic disturbance and direct applications of fertilizer N (Bauder et al., 1993). The cropping system soil $(10-30 \mathrm{~cm})$ has been shown to contain larger available $\mathrm{N}$ pools with slower turnover than the riparian area (Davis et al., 2006). Potentially lower microbial activity (lower DIC) in the cultivated soils (Horwath et al., 1998) may have led to microbial respiration using primarily $\mathrm{O}_{2}$, and to a lesser degree, $\mathrm{NO}_{3}$. Since $\mathrm{Fe}(\mathrm{II})$ and $\mathrm{Mn}(\mathrm{II})$ concentrations were much lower in the cropping system compared with the riparian area, autotrophic denitrification might not have played a large role. In the cropping system, DOC concentrations in 1997-1998 were 
relatively high ( $\left.>5 \mathrm{mg} \mathrm{C} \mathrm{L}{ }^{-1}\right)$ in winter when $\mathrm{NO}_{3}$ reduction was occurring. The rapid spring drop in DOC did not occur with a significant drop in $\mathrm{NO}_{3}$ concentrations. As soils warmed, aerobic respiration likely led to the spring decrease in cropping system DOC. However, even when cropping system concentrations of DO were relatively high $\left(>2 \mathrm{mg} \mathrm{O}_{2} \mathrm{~L}^{-1}\right)$, soil heterogeneity most likely would have allowed for some portion of $\mathrm{NO}_{3}$ to be consumed by denitrification in localized zones or hotspots (Groffman et al., 1996; Cey et al., 1999). Gambrell et al. (1975) reported $\mathrm{NO}_{3}$ reduction in an aerobic soil (redox 500-600 mV) and concluded that denitrification occurred in anaerobic microsites.

Even though subsoils have been shown to have lower microbial activity compared with surface soils (Parkin and Meisinger, 1989; Lowrance, 1992), $\mathrm{C}$ horizon $\mathrm{NO}_{3}$ and $\mathrm{DO}$ were consumed in the $\mathrm{C}$ horizon over the water year in both the riparian area and cropping system. However, significantly lower $\mathrm{NO}_{3}$ and DO concentrations in the riparian area shows that the redox gradient between the riparian area and cropping system existed even to this depth. Wells placed between the last row of riparian and first row of cropping system wells show that the decrease in $\mathrm{NO}_{3}$ was more gradual in the $\mathrm{C}$ horizon, indicating slower processing with depth. Lower Fe(II) and $\mathrm{Mn}$ (II) concentrations in the C compared with the A horizon showed that the subsoil was not as highly reduced as the surface soil.

The near-fallow conditions present during the transition from perennial ryegrass seed to no-till clover in the cropping system in combination with lower DOC were most likely responsible for higher $\mathrm{NO}_{3}$ on site in 1998 1999. Even though no-till soils generally produce lower $\mathrm{NO}_{3}$ levels than conventionally tilled soils (Fenster and Peterson, 1979), soil disturbance with direct drilling of clover seed in early fall of 1998, compared with $4 \mathrm{yr}$ of no disturbance, may have contributed some $\mathrm{NO}_{3}$ from the mineralization of microbial biomass and soil organic matter N. Nitrate concentrations have been shown to be higher in fallow periods than where a crop was established (Khanna, 1981). Since clover establishment was poor until late spring 1999, plant $\mathrm{N}$ uptake would have been negligible during fall and winter, resulting in greater $\mathrm{N}$ loss to soil water. Therefore, higher $\mathrm{NO}_{3}$ concentrations in water year 1998-1999 were likely due to a greater supply of $\mathrm{NO}_{3}$ than demand for it (Nelson et al., 2006). A greater load of $\mathrm{NO}_{3}$ from the cropping system to the riparian area in 1998-1999 did not increase $\mathrm{NO}_{3}$ concentrations within the riparian soil indicating that the riparian area was capable of processing increased $\mathrm{NO}_{3}$ loads.

One scenario to consider was that water flowed slow enough through the soil that $\mathrm{NO}_{3}$-laden groundwater did not travel very far into the riparian area during the water year and that with these slow flow rates, DO and $\mathrm{NO}_{3}$ were consumed even in soil with low DOC (Puckett et al., 2002) and microbial activity (subsoil). Groundwater velocity was calculated using saturated hydraulic conductivity estimates from the same region and soil type and at similar depths as our current study (Warren, 2002), a hydraulic gradient of 0.02 and a porosity of 0.44 .
Velocity estimates in the A horizon ranged from 0.4 to $1.1 \mathrm{~m} \mathrm{~d}^{-1}$, indicating that water could move from 48 to $133 \mathrm{~m}$ over the course of the saturated period (121 d). Since the riparian area is only 30 to $48 \mathrm{~m}$ wide, even low velocity estimates would allow shallow groundwater containing $\mathrm{NO}_{3}$ in the cropping system to move completely through the riparian area. Because of the highly reduced conditions in the riparian soil, it is likely that when $\mathrm{NO}_{3}$ entered the riparian area in groundwater from the cropping system, it was quickly consumed. In the $\mathrm{C}$ horizon, velocity ranged from 0.01 to $1.68 \mathrm{~m} \mathrm{~d}^{-1}$ indicating that water could move as little as $1.2 \mathrm{~m}$ and up to $203 \mathrm{~m}$ over the saturated period. This wide range of values makes it difficult to determine if low $\mathrm{C}$ horizon $\mathrm{DO}$ and $\mathrm{NO}_{3}$ in the riparian area was due to sufficient biological activity or to slow water movement. It was likely that the actual velocity was somewhere in the middle of the range. Either way, the $\mathrm{C}$ horizon soil was capable of removing nitrate in incoming groundwater. Wigington et al. (2003) found that most stream water at this site originates from overland flow through the cropping system. Although only a small portion of incoming water interacts with the riparian soils, this poorly drained riparian system was very efficient at removing $\mathrm{NO}_{3}$ from shallow groundwater.

Additional research is required to better evaluate surface and subsurface $\mathrm{NO}_{3}$ consuming process rates and their controlling factors, especially the dominant electron donors. Determining the significance of denitrification vs. dissimilatory nitrate reduction to ammonium would also add to the understanding of the ability of these systems to process or retain $\mathrm{N}$.

\section{CONCLUSIONS}

Data from this study suggest that both dilution from precipitation in the early water year and biological consumption, most likely plant uptake (A horizon only) and denitrification, were responsible for decreases in soil water $\mathrm{NO}_{3}$ seen as water moved from the cropping system into the riparian area. The riparian area had biologically active $\mathrm{A}$ and $\mathrm{C}$ horizons. Oxygen and $\mathrm{NO}_{3}$ were consumed early in the water year, creating a reductive zone where incoming $\mathrm{NO}_{3}$ was rapidly consumed. Although the transition of the cropping system from a fourth year perennial ryegrass crop to no-till clover produced higher groundwater $\mathrm{NO}_{3}$ concentrations, the $\mathrm{A}$ and $\mathrm{C}$ horizon riparian soil remained efficient, able to process all incoming $\mathrm{NO}_{3}$, limiting the contribution of groundwater at this site to $\mathrm{NO}_{3}$ in stream flow. However, stream flow at this site is dominated by overland runoff, greatly limiting the impact the riparian area can have on surface water quality.

\section{ACKNOWLEDGMENTS}

We would like to thank John Baham, Herb Huddleston, and Roy Haggerty for their helpful comments and review of this paper. The use of trade, firm, or corporation names in this publication (or page) is for the information and convenience of the reader. Such use does not constitute an official endorse- 
ment or approval by the United States Department of Agriculture or the Agricultural Research Service of any product or service to the exclusion of others that may be suitable.

\section{REFERENCES}

Aulakh, M.S., J.W. Doran, and A.R. Mosier. 1992. Soil denitrificationSignificance, measurement, and effects of management. p. 1-57. In B.A. Stewart (ed.) Advances in Soil Science, Vol. 18. SpringerVerlag, New York.

Baham, J.E., R. Roland, S.M. Griffith, and G. Grathoff. 1999. Biogeochemistry of $\mathrm{Fe}$ and $\mathrm{Mn}$ in a seasonally reduced riparian soil. AGU, San Francisco, CA.

Balesdent, J., A. Mariotti, and D. Boisgontier. 1990. Effect of tillage on soil organic carbon mineralization estimated from 13C abundance in maize fields. J. Soil Sci. 41:587-596.

Bauder, J.W., K.N. Sinclair, and R.E. Lund. 1993. Physiographic and land use characteristics associated with nitrate-nitrogen in Montana groundwater. J. Environ. Qual. 22:255-262.

Boersma, L., G.H. Simonson, and D.G. Watts. 1972. Soil morphology and water table relations: I. Annual water table fluctuations. Soil Sci. Soc. Am. Proc. 36:644-648.

Böhlke, J.K., and J.M. Denver. 1995. Combined use of groundwater dating, chemical, and isotopic analyses to resolve the history and fate of nitrate contamination in two agricultural watersheds, Atlantic coastal plain, Maryland. Water Resour. Res. 31:2319-2339.

Böhlke, J.K., R. Wanty, M. Tuttle, G. Delin, and M. Landon. 2002. Denitrification in the recharge area and discharge area of a transient agricultural nitrate plume in a glacial outwash sand aquifer, Minnesota. Water Resour. Res. 38:1105-1131.

Cey, E.E., D.L. Rudolph, R. Aravena, and G. Parkin. 1999. Role of the riparian zone in controlling the distribution and fate of agricultural nitrogen near a small stream in southern Ontario. J. Contam. Hydrol. 37:45-67.

Davis, J.H. 2003. Role of a grass riparian zone in controlling the fate of nitrogen in a poorly drained agricultural landscape. Ph.D. diss. Oregon State Univ., Corvallis, OR.

Davis, J.H., S.M. Griffith, W.R. Horwath, J.J. Steiner, and D.D. Myrold. 2006. Fate of nitrogen-15 in a perennial ryegrass seed field and herbaceous riparian area. Soil Sci. Soc. Am. J. 70:909-919.

Dillaha, T.A., R.B. Reneau, S. Mostaghimi, and D. Lee. 1989. Vegetative filter strips for agricultural nonpoint source pollution control. Trans. ASAE 32:513-519.

Fenster, C.R., and G.A. Peterson. 1979. Effects of no-tillage fallow as compared to conventional tillage in a wheat-fallow system. Nebraska Agricultural Experiment Station Res. Bull. 289:28. Nebraska Agricultural Experiment Station, Lincoln, NE.

Gambrell, R.P., J.W. Gilliam, and S.B. Weed. 1975. Denitrification in subsoils of the North Carolina coastal plain as affected by soil drainage. J. Environ. Qual. 4:311-316.

Gast, R.G., W.W. Nelson, and J.M. Macgregor. 1974. Nitrate and chloride accumulation and distribution in fertilized tile-drained soils. J. Environ. Qual. 3:209-213.

Gillham, R.W. 1991. Nitrate contamination of groundwater in southern Ontario and the evidence for denitrification. p. 181-198. In I. Bogardi and R.D. Kuzelka (ed.) NATO ASI Series. Series G: Ecological Sciences. Springer-Verlag, New York.

Goldstein, W.A., M.J. Scully, D.H. Kohl, and G. Shearer. 1998. Impact of agricultural management on nitrate concentrations in drainage waters. Am. J. Alternative Agric. 13:105-110.

Groffman, P.M., G. Howard, A.J. Gold, and W.M. Nelson. 1996. Microbial nitrate processing in shallow groundwater in a riparian forest. J. Environ. Qual. 25:1309-1316.

Haycock, N.E., and G. Pinay. 1993. Groundwater nitrate dynamics in grass and poplar vegetated riparian buffer strips during the winter. J. Environ. Qual. 22:273-278.

Hill, A.R. 1996. Nitrate removal in stream riparian zones. J. Environ. Qual. 25:743-755.

Horwath, W.R., L.F. Elliott, J.J. Steiner, J.H. Davis, and S.M. Griffith. 1998. Denitrification in cultivated and noncultivated riparian areas of grass cropping systems. J. Environ. Qual. 27:225-231.

Israel, D., W.J. Showers, M. Fountain, and J. Fountain. 2005. Nitrate movement in shallow groundwater from swine-lagoon-effluent spray fields managed under current application regulations. J. Environ. Qual. 34:1828-1842.

Jacobs, T.J., and J.W. Gilliam. 1985. Riparian losses of nitrate from agricultural drainage waters. J. Environ. Qual. 14:472-478.

Khanna, P.K. 1981. Leaching of nitrogen from terrestrial ecosystemsPatterns, mechanisms, and ecosystem responses. p. 343-352. In F.E. Clark and T. Roswall (ed.) Terrestrial nitrogen cycles. Kluwer Academic Publ., Stockholm.

Korom, S.F. 1992. Natural denitrification in the saturated zone: A review. Water Resour. Res. 28:1657-1668.

Lowrance, R.R. 1992. Groundwater nitrate and denitrification in a coastal plain riparian forest. J. Environ. Qual. 21:401-405.

Lowrance, R.R., R.L. Todd, and L.E. Asmussen. 1984a. Nutrient cycling in an agricultural watershed: I. Phreatic movement. J. Environ. Qual. 13:22-27.

Lowrance, R.R., R.L. Todd, J.F. Jr, J.O. Hendrickson, R. Leonard, and L. Asmussen. 1984b. Riparian forests as nutrient filters in agricultural watersheds. Bioscience 34:374-377.

Martin, T.L., N.K. Kaushik, J.T. Trevors, and H.R. Whitely. 1999. Denitrification in temperate climate riparian zones. Water Air Soil Pollut. 111:171-186.

McAllister, L.S., K.A. Dwire, and S.M. Griffith. 2000. Vegetation characterization of three contrasting riparian sites, Willamette Valley, Oregon. p. 29-33. In P.J. Wigington, Jr. and R.L. Beschta (ed.) International Conference on Riparian Ecology and Management in Multi-Land Use Watersheds., Vol. TPS-00-2. American Water Resources Assoc., Middleburg, VA.

Meek, B.D., L.B. Grass, L.S. Willardson, and A.J. MacKenzie. 1970. Nitrate transformations in a column with a controlled water table. Soil Sci. Soc. Am. Proc. 34:235-239.

Mengis, M., S.L. Schiff, M. Harris, M.C. English, R. Aravena, R.J. Elgood, and A. MacLean. 1998. Multiple geochemical and isotopic approaches for assessing groundwater nitrate elimination in a riparian zone. Ground Water 37:448-457.

Nelson, M.A., S.M. Griffith, and J.J. Steiner. 2006. Tillage effects on nitrogen dynamics and grass seed crop production in Western Oregon, USA. Soil Sci. Soc. Am. J. 70:825-831.

Oregon Climate Service. 2005. Oregon climate data [Online]. Oregon State Univ., Corvallis, OR. Available at http://www.ocs.oregonstate. edu (verified 5 Jan. 2007).

Parkin, T.B., and J.J. Meisinger. 1989. Denitrification below the crop rooting zone as influenced by surface tillage. J. Environ. Qual. 18: 12-16.

Peterjohn, W.T., and D.L. Correll. 1984. Nutrient dynamics in an agricultural watershed: Observations on the role of a riparian forest. Ecology 65:1466-1475.

Pinay, G., and H. DeCamps. 1988. The role of riparian woods in regulating nitrogen fluxes between the alluvial aquifer and surface water: A conceptual model. Regulating Rivers. Res. Manage. 2: 507-516.

Puckett, L.J., and W.B. Hughes. 2005. Transport and fate of nitrate and pesticides: Hydrology and riparian zone processes. J. Environ. Qual. 34:2278-2292.

Puckett, L.J., T.K. Cowdery, P.B. McMahon, L.H. Tornes, and J.D. Stoner. 2002. Using chemical, hydrologic, and age dating analysis to delineate redox processes and flow paths in the riparian zone of a glacial outwash aquifer-stream system. Water Resour. Res. 38: 1134-1154.

Reddy, K.R., and W.H. Patrick. 1975. Effect of alternate aerobic and anaerobic conditions on redox potential, organic matter decomposition, and nitrogen loss in a flooded soil. Soil Biol. Biochem. 7: 87-94.

Schnabel, R.R., L.F. Cornish, W.L. Stout, and J.A. Shaffer. 1996. Denitrification in a grassed and wooded, valley and ridge, riparian ecotone. J. Environ. Qual. 25:1230-1235.

Sokal, R.R., and F.J. Rohlf. 1981. Biometry: The principles and practice of statistics in biological research. 2nd ed. W.H. Freeman, San Francisco.

SPSS, Inc. 2002. SPSS for Macintosh. Version 11.0. SPSS Inc., Chicago, IL.

Tesoriero, A.J., H. Liebscher, and S.E. Cox. 2000. Mechanism and rate of denitrification in an agricultural watershed: Electron and mass balance along groundwater flow paths. Water Resour. Res. 36: $1545-1559$. 
Tufekcioglu, A., J.W. Raich, T.M. Isenhart, and R.C. Schultz. 1999. Fine root dynamics, coarse root biomass, root distribution, and soil respiration in a multispecies riparian buffer in Central Iowa, USA. Agrofor. Syst. 44:163-174.

Verchot, L.V., E.C. Franklin, and J.W. Gilliam. 1997. Nitrogen cycling in piedmont vegetated filter zones: II. Subsurface nitrate removal. J. Environ. Qual. 26:337-347.

Warren, K. 2002. Transport of water and solutes from tile-drained fields in the Willamette Valley, OR: A field study. M.S. thesis. Oregon State Univ., Corvallis, OR.
Weiss, R.F. 1970. The solubility of nitrogen, oxygen, and argon in water and seawater. Deep-Sea Res. 17:721-735.

Wigington, P.J., S.M. Griffith, J.A. Field, J.E. Baham, W.R. Horwath, J. Owen, J.H. Davis, S.C. Rain, and J.J. Steiner. 2003. Nitrate removal effectiveness of a riparian buffer along a small agricultural stream in western Oregon. J. Environ. Qual. 32: $162-170$.

Young, R.A., T. Huntrods, and W. Anderson. 1980. Effectiveness of vegetated buffer strips in controlling pollution from feedlot runoff. J. Environ. Qual. 9:483-487. 